financial assistance and continuing encouragement. We are also grateful to Mr. C. Pratapkumar, biochemistry technologist, for technical help in the biochemical aspects of this study, to Professor Grace Koshy for acid-fast bacilli culture reports, to the staff of the Biostatistics and Data-Processing Unit, Christian Medical College, Vellore, for statistical help, and to Mr. S. Philip for secretarial assistance. It is a pleasure to acknowledge the encouragement and continuing support from Dr. Oliver Hasselblad, of the American Leprosy Missions, Inc., New York.

Requests for reprints should be addressed to Dr. A. B. A. Karat.

\section{References}

Binford, C. H. (1969), American fournal of Clinical Pathology, 51, 681. Brito, T. de, Carvalho, N., Marques, A. C. R., Penna, D. O., and Azevedo,

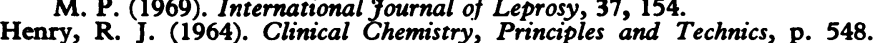
New York, Harper and Row.

Job, C. K., Karat, A. B. A., and Verghese, A. (1965). Leprosy in India, $37,358$.

Karat, A. B. A. (1966). International fournal of Leprosy, 34, 415.
Karat, A. B. A. (1970). Professional Profile in Leprosy. Awaiting publication. Karat, A. B. A., and Harmer, H. (1970). Studies in Viability of $M$. leprae in the Human Liver and Bone Marrow. Awaiting publication.

Kingsley, G. R. (1942). Fournal of Laboratory and Clinical Medicine, 27, 840. Ludin, F. E., and Ross, Sr. Hilary. (1959). International fournal of Leprosy, 27,43 .

Menghini, G. (1958). Gastroenterology, 35, 190

Quick, A. J. (1940). American fournal of Clinical Pathology, 10, 222.

Ridley, D. S. (1964). Leprosy in Theory and Practice, ed. R. G. Cochrane and T. Frank Davey, 2nd edn., p. 620. Bristol, Wright.

Ridley, D. S., and Jopling, W. H. (1966). International fournal of Leprosy, 34,255 .

Shivde, A. V., and Junnarkar, R. V. (1967). International fournal of Leprosy, 35,366 .

Smith, E. D. I. (1960). Chromatographic and Electrophoretic Technique, Vol. 2: Zone Electrophoresis, p. 57. London, Heinemann.

Sood, V. K., and Grueber, H. L. (1969). International fournal of Leprosy, $37,28$.

Varley, H. (1962). Tests in Liver and Biliary Tract Disease. Practical Clinical Biochemistry, 3rd edn., p. 305. Heinemann Medical Books.

Verghese, A., and Job, C. K. (1965). International fournal of Leprosy, 33, 342.

Wade, H. W. (1964). Leprosy in Theory and Practice, ed. R. G. Cochrane and T. Frank Davey, 2nd edn., p. 613. Bristol, Wright.

Wootton, I. D. P. (1964). Microanalysis in Medical Biochemistry, 4th edn., p. 101. London, Churchill.

\title{
Effect of Psychiatric Intervention in Attempted Suicide: A Controlled Study
}

\author{
STEVEN GREER, CHRISTOPHER BAGLEY
}

British Medical fournal, 1971, 1, 310-312

\section{Summary}

All patients presenting at the casualty department of King's College Hospital during the first six months of 1968 with deliberate self-poisoning or self-injury were followed up. Of 211 patients $204(97 \%)$ were traced after a mean interval of 18 months (range one to two years). Despite official hospital policy, $22 \%$ had not been seen by a psychiatrist before discharge; these 44 untreated patients were compared with the remaining 160 who had received either brief (one or two interviews) or more prolonged psychiatric and social help.

Subsequent suicidal attempts occurred significantly more often among untreated than among treated patients, prolonged treatment being associated with the best prognosis. The same trend was observed in respect of actual suicide, though the numbers were small and differences did not reach statistical significance. These findings held good when the untreated and treated groups were controlled for other variables which were found to be correlated with outcome. These results indicate that psychiatric intervention is associated with a significant reduction in subsequent suicidal behaviour.

\section{Introduction}

Each year at least 50,000 patients are admitted to hospital in Britain following deliberate self-poisoning or self-injury (Roberts and Hooper, 1969; Bagley, 1971). The rate of such

\section{King's College Hospital, London S.E.5}

STEVEN GREER, M.D., D.P.M., Senior Lecturer, Department of Psychological Medicine

Institute of Psychiatry, London S.E.5

CHRISTOPHER BAGLEY, PH.D., Research Fellow, M.R.C. Social Psychiatry. Research Unit. (Present appointment: Scientific Member, Centre for Social Research, University of Sussex, Brighton) "parasuicide" (Kreitman et al., 1969) is increasing each year, probably by as much as $10 \%$ per annum (Aitken et al., 1969; Bagley, 1971). Many will repeat the attempt (Kessel and McCulloch, 1966), and the more often a patient attempts suicide the more likely it is that he will kill himself (Ettlinger, 1964).

In 1961 the Ministry of Health issued a circular to all hospitals recommending that any patient admitted to a casualty department should be seen by a psychiatrist before discharge. A more recent report of the Central Health Services Council (1968) again recommended that "all cases of deliberate selfpoisoning should receive psychological and social evaluation and help." Despite these recommendations there is virtually no information on the efficacy of psychiatric treatment in preventing further suicidal attempts, though it is known that voluntary services (Bagley, 1968) and a community care service for old people (Walk, 1967) can have a beneficial effect on suicide rates. Hitherto, reported follow-up studies of attempted suicides-for example Schmidt et al. (1954), Ruegsegger (1963), Ettlinger (1964), Kessell and McCulloch (1966), Greer and Lee (1967)-have been confined to patients who received psychiatric treatment of some kind. The absence of any data about the progress of untreated patients is, of course, due to the ethical problems of conducting controlled studies in this area. In the present study an untreated group of patients was made available by an artefact of medical policy.

\section{Patients and Methods}

The records of all patients (about 25,000) who presented at King's College Hospital casualty department during the first six months of 1968 were examined. By this means 211 cases of parasuicide were obtained for study. It was discovered that $22 \%$ of these patients had not been seen by a psychiatrist at the time of their attempt, either because the attending doctornotwithstanding official hospital policy-had discharged the patient without psychiatric referral or, in some cases, because the patient apparently refused such referral. The remaining patients were divided into two groups according to the 
amount of psychiatric treatment which they received. The present series thus comprised: (1) an untreated Experimental Group ( $n=47)$; (2) a briefly treated Control Group $1(n=76)$, where psychiatric contact was limited to a maximum of two interviews; and (3) Control Group $2(\mathrm{n}=88)$, who received more prolonged psychiatric treatment.

Patients were followed up retrospectively 12 to 24 months after the key attempt; the mean follow-up interval was 18 months for each group. Where initial contact by letter failed patients were traced through their general practitioners, mental hospitals, and various social agencies. General Register Office records were examined for death entries in respect of all untraced cases. Detailed clinical and social data were obtained by means of structured interviews with patients and, where possible, relatives, as well as from hospital records. The seriousness of the suicidal attempt was rated according to Kessel's Index of Endangering Life (Kessel, 1966) in terms of $(a)$ the medical consequences and $(b)$ the patient's action in avoiding or ensuring discovery.

\section{Results}

We were able to trace 204 patients, representing $97 \%$ of the original sample. Fifty-three patients $(26 \%)$ had made a further suicide attempt in the follow-up period; a further four $(2 \%)$ had killed themselves; four patients died of natural causes. Two of these cases of natural death were excluded from the analysis because of lack of information. Table I

\begin{tabular}{|c|c|c|c|c|}
\hline Outcome & $\begin{array}{c}\text { Experimental } \\
\text { Group. No } \\
\text { Psychiatric } \\
\text { Contact }\end{array}$ & $\begin{array}{l}\text { Controls } 1 . \\
\text { Brief Contact- } \\
\text { No more than } \\
\text { two interviews }\end{array}$ & $\begin{array}{c}\text { Controls 2. } \\
\text { More Prolonged } \\
\text { Psychiatric } \\
\text { Contact }\end{array}$ & Total \\
\hline $\begin{array}{l}\text { No S.A. } \\
\text { Further S. } \\
\text { Suicide } \\
\text { Other deaths }\end{array}$ & $\begin{array}{l}24(55 \%) \\
17(39 \%) \\
2(4.5 \%) \\
1(2 \%)\end{array}$ & $\begin{array}{l}52(71 \%) \\
19(26 \%) \\
1(1.4 \%) \\
1(1.4 \%)\end{array}$ & $\begin{array}{l}67(77 \%) \\
17(20 \%) \\
1(1 \cdot 1 \%) \\
2(2 \cdot 3 \%)\end{array}$ & $\begin{array}{r}143(70 \%) \\
53(26 \%) \\
4(2 \%) \\
4(2 \%)\end{array}$ \\
\hline Total & 44 & 73 & 87 & 204 \\
\hline $\begin{array}{l}\text { Untraced } \\
\text { Grand total }\end{array}$ & $\begin{array}{r}3 \\
47\end{array}$ & $\begin{array}{r}3 \\
76\end{array}$ & 88 & $211^{7}$ \\
\hline \multicolumn{5}{|c|}{ S.A. = Suicidal attempt. } \\
\hline
\end{tabular}

shows that $39 \%$ of the Experimental Group had repeated an attempt, compared with $26 \%$ of Control Group 1 and $20 \%$ of Control Group 2. Two of the suicides occurred in the untreated (experimental) group, and one each in the two control groups.

The differences with respect to further suicidal attempts between the Experimental and Control Group 2 and between the Experimental and both Control Groups combined are statistically significant. The same trend can be seen when comparing the outcome in the Experimental Group with that in Control Group 1, but the differences here do not reach statistical significance. Patients in Control Group 1, it will be recalled, had only brief psychiatric contact at the time of the suicidal attempt. A number of these patients, however, subsequently obtained further psychiatric treatment during the follow-up period. Their outcome was found to be significantly better than that of the remaining patients in Control Group 1 (Table II).

It is necessary to ascertain whether the differences in outcome between the Experimental and Control Groups are a function of variables other than treatment. The associations of 30 clinical and social variables with outcome were therefore examined. Five factors were significantly related to prognosis: (1) a history of previous suicidal attempts, (2) a diagnosis of antisocial personality disorder, alcoholism, or drug
TABLE II-Control Group 1: Subsequent Psychiatric Help and Outcome

\begin{tabular}{|c|c|c|c|c|c|c|}
\hline & & & & $\begin{array}{c}\text { Subsequent } \\
\text { Psychiatric Help }\end{array}$ & $\begin{array}{l}\text { No Subsequent } \\
\text { Psychiatric Help }\end{array}$ & Total \\
\hline $\begin{array}{l}\text { No S.A. } \\
\text { Further S.A. } \ldots\end{array}$ & $\cdots$ & $\ldots$ & $\because$ & $20\left(\begin{array}{c}91 \%) \\
(9 \%)\end{array}\right.$ & $\begin{array}{l}32(65 \%) \\
17(35 \%)\end{array}$ & $\begin{array}{l}52 \\
19\end{array}$ \\
\hline Total .. & $\ldots$ & $\ldots$ & .. & 22 & 49 & 71 \\
\hline
\end{tabular}

Significance of Differences

Further S.A.: Subsequent psychiatric help $v$. No further help, $t=2 \cdot 25 \pm 0 \cdot 11$, $\mathrm{P}<0.05$.

TABle III-Other Significant Prognostic Factors

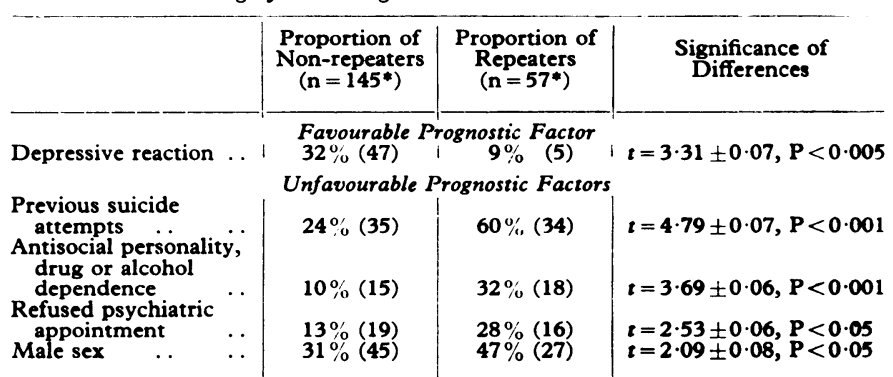

* Two cases of natural death, with insufficient information, have been excluded.

dependence, (3) refusal of psychiatric help, and (4) male sexthese were each associated with poor outcome-that is, repetition of suicidal acts; (5) a diagnosis of depressive reaction, on the other hand, was associated with a favourable outcome (Table III). Among the variables which were unrelated to outcome was the seriousness of the suicidal attempt. Neither the degree of medical danger nor the patient's action in avoiding or ensuring discovery was of prognostic significance.

In order to control for the effect of the significant prognostic variables in examining the relationship between psychiatric treatment and repeated attempts, the three groups have been equalized for the proportion of cases containing these five variables (Table IV). This has meant a reduction in the number of cases analysed to 172 . Nevertheless, the differences between experimental and both control groups remain significant. The difference is actually enhanced because of the reduction in the proportion of cases with unfavourable prognostic variables in the experimental group.*

TABLE IV-Psychiatric Treatment and Outcome after Controlling for Other Significant Prognostic Factors

\begin{tabular}{l|c|c|c|c|} 
& $\begin{array}{c}\text { Experimental } \\
\text { Group.* } \\
\text { No } \\
\text { Treatment } \\
(n=33)\end{array}$ & $\begin{array}{c}\text { Control } \\
\text { Group 1.* } \\
\text { Brief } \\
\text { Treatment } \\
(\mathrm{n}=60)\end{array}$ & $\begin{array}{c}\text { Control } \\
\text { Group 2.* } \\
\text { More } \\
\text { Prolonged } \\
\text { Treatment } \\
(\mathrm{n}=79)\end{array}$ & $\begin{array}{c}\text { Controls } \\
1+2 . \\
\text { All } \\
\text { Treatment } \\
(\mathrm{n}=139)\end{array}$ \\
\hline $\begin{array}{c}\text { Further suicidal } \\
\text { attempts and } \\
\text { suicide } . .\end{array}$ & $\ldots 8.5 \%(16)$ & $28 \%(17)$ & $19 \%(15)$ & $23 \%(32)$ \\
\hline
\end{tabular}

- Groups equalized for proportions with other significant prognostic factors (Table Further Suicidal Attempts and Suicide:

No treatment $v$. brief treatment: $t=1.94+0.1, P=0.05$

No treatment $v$. more prolonged treatment: $t=3 \cdot 19+0.09, \mathrm{P} \times 0.005$

\section{Discussion}

Considerable efforts and resources are devoted to the resuscitation and medical care of patients who have deliberately poisoned or injured themselves. By contrast, the psychiatric resources available for treating such patients are, to put it mildly, slender. A reflection of this state of affairs is the large proportion in the present series whose psychiatric treatment

* A multiple regression analysis using data on all cases indicates a similar result, the correlation coefficient between treatment and outcome being enhanced when all other variables are controlled (Bagley and Greer, 1971) 
was limited to one interview or occasionally two. Their prognosis tended to be worse than that of more intensively treated patients (Tables I and IV), and our results indicate that many of the patients who had only brief psychiatric contact subsequently benefited from further psychiatric treatment (Table II). The specific characteristics of patients who benefit mostand least-from psychiatric treatment will be described in a subsequent paper (Bagley and Greer, 1971).

It was surprising to discover that more than one-fifth of the present series had no psychiatric contact whatsoever following their suicidal attempt. In most cases these patients were sent home because the casualty officer considered that there was no medical danger and the suicidal attempt was therefore a trivial matter. Our findings indicate that this assumption is both mistaken, since the degree of medical danger was not related to prognosis, and dangerous, since $39 \%$ of untreated patients made further suicidal attempts and $4.5 \%$ killed themselves within 18 months. These results lend force to the Central Health Services Council's (1968) recommendations: "All cases of deliberate self-poisoning should be referred to a designated poisoning centre, regardless of the seriousness or otherwise of their medical condition ... they should never be sent home without undergoing psychiatric assessment."

The present study shows that psychiatric treatment was associated with a significant fall in incidence of subsequent suicidal attempts. Since untreated patients are particularly liable to repeat suicidal attempts, and since multiple suicidal attempts increase the probability of eventual suicide (Ettlinger, 1964), it seems likely that adequate facilities for psychiatric treatment could save lives as well as reduce the repeat rate for parasuicide.

We thank the patients whose co-operation made this study possible; Professor J. Anderson and Dr. D. Liddell for their encouragement; and Mr. I. Corkindale, who searched the General Register Office records for death entries. The study was generously supported by King's College Hospital Medical School research funds.

Requests for reprints should be addressed to Dr. S. Greer, King's College Hospital, London, S.E.5.

\section{References}

Aitken, R., Buglass, D., and Kreitman, N. (1969). British fournal of Preventive and Social Medicine, 23, 111.

Bagley, C. (1968). Social Science and Medicine, 2, 1.

Bagley, C. (1968). Social Science and Medicine, 2, 1.

Bagley, C. (1971). Social and Economic Administra

Bagley, C., and Greer, S. (1971). In preparation. Poisoning. London, H.M.S.O.
Health Services Council

Ettlinger, R. (1964). Acta Psychiatrica Scandinavica, 40, 363.

Greer, S., and Lee, H. (1967). Acta Psychiatrica Scandinavica, 43, 361.

Kessel, N. (1966). Fournal of Psychosomatic Research, 10, 29.

Kessel, N., and McCulloch, W. (1966). Proceedings of the Royal Society of Medicine, 59, 89.

Kreitman, N., Philip, A., Greer. S., and Bagley, C. (1969). British fournal of Psychiatry, 115, 746 .

Ministry of Health (1961). H.M. (61). 94.

Roberts, J., and Hooper, D. (1969). British fournal of Medical Psychology, 42, 303 .

Ruegsegger, P. (1963). Psychiatria et Neurologia, 146, 81.

Schmidt, E., O'Neal, P., and Robins, E. (1954). Fournal of the American Medical Association, $155,549$.

Walk, A. (1967). British Fournal of Psychiatry, 113, 1381.

\title{
Prevention of Postoperative Deep Venous Thrombosis and Pulmonary Embolism
}

\author{
A. E. CARTER, R. EBAN, R. D. PERRETT
}

British Medical fournal, 1971, 1, 312-314

\section{Summary}

Two series of patients observed clinically and by phlebography suggest that one agent known to produce a reduction in platelet aggregation in vitro might be useful in reducing the incidence of deep venous thrombosis and pulmonary embolism postoperatively. The agent used in this study was hydroxychloroquine sulphate.

\section{Introduction}

Postoperative lower limb venous thrombosis causes discomfort, delay in discharge from hospital, and disability that may last throughout life. Moreover, it is believed to be the precedent to pulmonary embolism, an event responsible for death in as few as $6 \%$ and, possibly, as many as $28 \%$ of hospital deaths (Morrell and Dunhill, 1968), all of which are, at least in theory, preventable. The incidence of venous thrombosis

King Edward Memorial Hospital, London W.13 A. E. CARTER, F.R.C.S., Consultant Surgeon R. EBAN, M.R.C.P., F.F.R., Consultant Radiologist

R. D. PERRETT, F.R.C.S., Surgical Registrar (at present Senior Surgical Registrar, Prince Henry Hospital, Little Bay, N.S.W., Australia) in various series of patients ill enough to be in hospital or subjected to surgery varies widely, depending on the criteria used to make the diagnosis; the more accurate the diagnosis the higher the rate-from $8 \%$ (Stadil, 1968) to $83 \%$ (Sevitt and Innes, 1964). Negus and Pinto (1968) suggested that in people over the age of 50 years undergoing major surgery the rate may be as high as $34 \%$.

The observation by Payling Wright (1941) that, in association with surgical procedures, the platelets' capacity to adhere together is increased has stood the test of repeated proof. Aggregation of platelets as a precedent to thrombosis may possibly be a not dissimilar process from the red cell "sludging" that occurs in trauma and infection as described by Knisely et al. (1941). Madow (1960) showed that red cell "sludging" could be reduced by several antimalarial agents, and he reported, in particular, the effect of hydroxychloroquine sulphate in this respect. It seemed possible, therefore, that hydroxychloroquine sulphate might reduce the propensity of platelets to adhere in traumatic situations and that, if it did without inducing a tendency to bleed or other complications, it might thereby reduce the incidence of deep venous thrombosis and pulmonary embolism in patients submitted to surgery.

The diagnosis of venous thrombosis solely by clinical signs is unreliable; phlebography is highly accurate and simple (Thomas, 1970). A combination of phlebography and clinical signs can serve as a guide to the effects of agents used to try to prevent thrombosis, and this report concerns one such agent investigated by these means. 